\title{
ABILITY TO FOSTER SCHOOLCHILDREN'S ECOLOGICAL LITERACY AS A RESULT OF PROSPECTIVE BIOLOGY TEACHERS' PROFESSIONAL TRAINING
}

\author{
Mariia Bilianska \\ National Pedagogical Dragomanov University, Ukraine \\ E-mail: mbilianska@ukr.net \\ Olga Yaroshenko \\ Institute of Higher Education of the National Academy of \\ Educational Sciences of Ukraine, Ukraine \\ E-mail: o.yaroshenko@ihed.org.ua
}

\begin{abstract}
An important role in preventing the negative effects of human impact on the environment is played by environmental literacy, which is connected with developing the ability to use natural resources wisely and reduce waste as well as awareness of the role of the environment for safe and healthy living.

The scientific studies on formation of students' ecological literacy were analyzed. It was revealed that the current state of training future Biology teachers for developing students' environmental literacy is not efficient. Ability of prospective Biology teachers to form students' ecological literacy is identified by the unity of value, cognitive and procedural components. Theoretical substantiation of the technology of training future Biology teachers for increasing students' ecological literacy is carried out. The peculiarity of the technological process is the study of the elective courses "Conducting Ecological Pedagogical Activities", "Technologies of Environmental Education and Upbringing", "Methods of Teaching Ecology", use of interactive teaching methods, combination of training sessions, independent work, practical training, and control measures. Criteria for the formation of each component are students' attitude to the environment and its preservation, the level of knowledge acquisition, the level of mastery of the methods of developing school students' environmental literacy. A three-level approach to evaluating the results was used. The average level of formation of each component dominated. During the experimental training, statistically significant positive changes in the formation of each component took place. This confirms the feasibility of further implementation of the technology.
\end{abstract}

Keywords: ecological literacy, elective courses, environmental upbringing, pre-service biology teachers

\section{Introduction}

Mastering ecological literacy is essential for preservation of the environment and obtaining basic rules of behavior in nature. Ensuring the sustainable development of society requires solving global environmental problems such as climate change, pandemics, the effects of human pollution, irrational use of natural resources, and so on. The UN Sustainable Development Goals (Global Goals) (2015) enhanced the importance of ecological literacy in general and students' in particular. This makes environmental pedagogical activities an integral part of teachers' professional activities. They organize and conduct environmental activities during classes, hold extracurricular and after school activities, enhance students' desire to protect and preserve the environment. 
Mariia BILIANSKA, Olga YAROSHENKO. Ability to foster schoolchildren's ecological literacy as a result of prospective biology teachers' professional training

PROBLEMS

OF EDUCATION IN THE $21^{\text {st }}$ CENTURY Vol. 78, No. 6, 2020

908

The modern educational process in Ukrainian institutions of complete general secondary education is aimed at shaping schoolchildren's key competencies, one of which is ecological literacy. At present, Ukrainian scientists adhere to the views of ecological literacy as "the ability to use natural resources wisely and rationally in the framework of sustainable development, awareness of the role of the environment for human life and health" (The new Ukrainian School. Conceptual principles of secondary school reform, 2016, p. 12).

Ecological literacy of teachers of natural sciences is important, because in the future, they will work on its formation in students. This view is also confirmed by the research (Turner et al., 2009) that the formation of environmental literacy of students will be successful provided that teachers have gained environmental knowledge. Aksan and Çelikler (2020) also substantiated the need for awareness of teachers of natural sciences with environmental problems, in particular on the reduction of waste and the need for their processing in terms of the concept of sustainable development.

Analysis of scientific works has shown that ecological literacy is the subject of research by many domestic and foreign scientists. "Ecological literacy is the ability to understand the natural system that is related to our life. It is a way of thinking about the world in terms of interactions within natural systems including a consideration of the consequences of human actions. An ecological literacy equips students with the knowledge and competencies necessary to address solution of environmental issues in an integrated way" (Adawiah \& Esa, 2013). Panfilova (2002) interpreted ecological literacy as people's ability to participate competently in activities aimed at preventing and eliminating damage caused to nature by industrial activities. McBride et al. (2013) connected ecological literacy with awareness of environmental care, knowledge, skills, motives for solving environmental problems and preventing their occurrence.

Orr (1992) considered ecological literacy from the point of view of the impact of human activity not only on the environment, but also on how this activity fits into the complex system (web) of ecological relationships within which we live. According to the researcher, future generations must become environmentally literate, i.e. learn how to interact with nature for mutual benefit. The concepts of ecological literacy and ecological awareness were used as identical in these studies. Berkowitz et al. (2005) interpreted ecological literacy as a combination of environmental education and civic literacy.

In 1989, UNESCO-UNEP positioned ecological literacy as the main goal of environmental education (McBride et al., 2013). This view is shared by the North American Association for Environmental Education (NAAEE, 2004). They highlight the following aspects of environmental education: awareness of local, regional and global environmental issues; ability to identify and analyze environmental problems, assess, seek, propose and justify solutions; ecological knowledge, knowledge of the ecological system, ecological problems and strategies for their solution; development of personal qualities (interest, sensitivity, self-control, responsibility, intention to act) (NAAEE, 2011).

It is logical that McBeth et al. (2008) distinguished the following components of ecological literacy: foundational ecological knowledge, environmental affect, cognitive skills, and pro-environmental behavior. Powers (2010) assumed ecological literacy to be based on ecological knowledge of Trade-offs, Succession, Element Cycles, Population Dynamics, and Global Ecology. The views of Jordan et al. (2009) slightly differed from the above-mentioned by focusing on the following components of ecological literacy: ecological connections and key concepts of ecology as a science (functional connections between species, between species and the environment; biotic and abiotic factors and their impact on distribution species, ecological processes); environmental scientific skills (modeling, awareness and understanding of the scale of the problem); human actions related to the impact on ecosystems. According to the researcher, ecological literacy allows a person to understand the connection of their own existence with environmental processes and helps to solve environmental problems. Students' 
ecological literacy includes knowledge of the following basic concepts: “...the ecosystem, succession, energy flow, conservation of resources, competition niche, materials cycling, the community, life history strategies, ecosystem fragility, food webs, ecological adaptation, environmental heterogeneity, species diversity, density dependent regulation, limiting factors, carrying capacity, maximum sustainable yield, population cycles, predator-prey interactions" (Adawiah \& Esa, 2013).

Researchers pay much attention to future teachers' environmental training. In particular, Traulko (2004) considered this training to be a component of both professional and general cultural education. The researcher sees its result in the psychological and practical readiness of graduates to make responsible and environmentally sound decisions in their professional activities. Panfilova (2002) characterized the ecological training of higher pedagogical education students as one that provides shaping their readiness for interaction with nature, for ecologically oriented educational work with adults (including students' parents), for environmental upbringing of schoolchildren, for shaping values during educational, scientific activities, various activities in nature fostering the need to preserve it.

Kaiser and Fuhrer (2003) emphasized that gaining knowledge about the functioning of ecological systems and natural processes (e.g. climate change, its causes and consequences), conservation of natural resources and environment, ways to preserve the environment, etc. is the key component of prospective specialists' ecological training. Boychenko and Sayenko (2013) defined the concept of ecological and creative training of higher education students, which is based on innovative learning, introducing new educational programs and disciplines in the educational process to develop students' ecological mindset. The factors influencing the behavior of teacher candidates in the environment were analyzed by Avaroğulları and Ayllmazdır (2019). Such behavior was described by the researchers taking into account gender, position, institution, level of training.

The Model of Environmental Education Competency Development for Teachers in Secondary School deserves special attention. The components of the competency are environmental knowledge, fundamental understanding on Environmental Education, responsibility on Environmental Education teacher actualization, Environmental Education planning and operating, promoting Environmental Education learning, and Environmental Education evaluation. Scientists focus on integrated learning and project activities. There are five steps in integrated learning: Analyzing the educational policy, Studying the community environmental problems, Designing the environmental learning project, Identifying the Standard of learning, Performing the integrated lesson plan (Wanchana et al., 2019).

The research carried out by Bilianska (2017) proved the importance of training preservice Biology teachers for ecological and pedagogical activities in order to develop students' ecological culture, enhance motives for preserving the environment, as well as to do educational work with parents and members of the teaching staff. Training future biology teachers for shaping students' ecological literacy was not included in the research aims.

Formation of a person's ecological literacy begins in the family and preschool education institution and continues in school, where it is carried out during the study of all subjects. Therefore, a teacher of any specialty must know and apply the basic methods and forms of environmental and pedagogical activities for fostering students' ecological literacy. Biology in this sense is marked by the fact that it creates a wide range of opportunities for developing the students' key competence that is chosen as a subject for the research. Therefore, preparedness for using these opportunities should become an important component of prospective biology teachers' training. The analysis of the results of scientific works and normative legal documents allowed to conclude that the ability of the future teacher to form students' ecological literacy is represented by the unity and interrelation of value, cognitive and procedural components. Their formation takes place in the process of studying the disciplines of the cycles of general and 
Mariia BILIANSKA, Olga YAROSHENKO. Ability to foster schoolchildren's ecological literacy as a result of prospective biology teachers' professional training

PROBLEMS

OF EDUCATION

IN THE $21^{\text {st }}$ CENTURY Vol. 78, No. 6,2020

910

professional training, as well as the cycle of elective disciplines. The analysis of the scientific papers showed that university training mainly focuses on shaping ecological literacy of higher education students. However, ecological literacy as one of the key competencies of school age children and the ability of future teachers to shape it have not been purposefully studied and need further research.

The purpose of the study was to improve the content of professional training of preservice Biology teachers by creating and applying optional disciplines in the educational process.

\section{Research Focus}

The research focused on the ways of training future Biology teachers for shaping students' ecological literacy in the process of studying elective disciplines "Conducting Ecological Pedagogical Activities", "Technologies of Ecological Education and Upbringing", "Methods of Teaching Ecology". The target was to develop technology to make students prepared for the type of professional activity. The objectives of the research were as follows: 1) to investigate pre-service Biology teachers' ability to form students' environmental literacy; 2) to develop and substantiate the technology of practice-oriented training and experimentally test its effectiveness in a real educational process.

\section{Research Methodology}

\section{General Background}

The research was conducted using the methods of pedagogical experiment (ascertaining and formative stages), and a survey. Experimental verification of the technology of training pre-service Biology teachers to shape students' ecological literacy was carried out in a real educational process without violating its integrity with applicants for the first (bachelor's) level of higher education in specialty "Secondary education (Biology)" during 2017/2019 years. The study involved undergraduate students of higher education institutions of Ukraine.

\section{Sample}

240 students took part in the pedagogical experiment (128 at the ascertaining and 112 at the formative stage), including 223 girls and 17 boys. The students studied both at public expense and at the expense of individuals. The selection was made by random sampling from four institutions of higher pedagogical education from different regions of Ukraine. The selection was based on the results of the final semester attestation of students with average, sufficient and high levels of academic achievement.

To establish the reliability of the obtained results the constant method was used, which does not involve the creation of control groups (Shtul'man, 1988). The research was carried out in the process of successive pedagogical experiment at its ascertaining and formative stages, and the dynamics of development of future Biology teachers' ability to increase students' ecological literacy was identified by comparing the results of two measurements, the initial and final.

In order to find out the attitude of in-service Biology teachers to the issue of shaping schoolchildren's ecological literacy, a survey was conducted. It involved 183 Biology teachers with work experience from 1 to 5 years from 109 schools located in cities and villages of Ukraine. 
Mariia BILIANSKA, Olga YAROSHENKO. Ability to foster schoolchildren's ecological literacy as a result of prospective biology teachers' professional training

PROBLEMS

OF EDUCATION

IN THE $21^{\text {st }}$ CENTURY

Vol. 78 , No. 6, 2020

Instrument and Procedures

The practical state of training pre-service Biology teachers for fostering students' ecological literacy was determined by the results of the ascertaining stage of the pedagogical experiment. The criterion of forming the value component of the ability to foster students' ecological literacy was chosen by students' attitude to the environment and its preservation, the indicator was the coefficient of forming value component $(C v)$. The criterion for forming the cognitive component of the studied phenomenon was the level of knowledge acquisition, and its indicator, the coefficient of knowledge acquisition $(C c)$. The formation of the procedural component was proved by the level of students' mastery of the method of increasing schoolchildren's environmental literacy, which was determined by a comprehensive indicator $(C p)$, that is methodically correct planning and conducting environmental activities with students, appropriate use of environmental information in the educational process.

Sharing the opinion of researchers (Kapskaya, 1989; Kuzmina, 1990; Molyako, 1989; Urus'kyy, 2005), a level approach to the studied phenomenon was applied. Three levels of pre-service Biology teachers' ability to form students' environmental literacy were singled out: low, average and high. The level of formation of the value component of future Biology teachers' ability to foster students' ecological literacy was determined by their attitude to the living beings, to themselves, to life as the highest value, awareness of personal involvement and responsibility for natural resources, motivation to preserve the environment and perception of nature as a source of wealth.

The formation of the procedural component of the studied phenomenon was proved by the following students' skills: cognitive (select and use environmental information in the process of teaching Biology; apply the educational potential of the school subject of Biology to increase students' ecological literacy); projective (set the goals and objectives of classes and predict their outcomes; plan activities for fostering students' ecological literacy); organizational (hold environmental activities such as excursions, ecological trails, environmental holidays, exhibitions, games, theaters, landscaping, environmental events, etc.); communicative (establish communication with students in the process of environmental activities, create an atmosphere of trust in communication); constructive (use tools, teaching methods to achieve goals and objectives, to transform scientific information into educational material and develop lesson outlines); evaluative reflexive (analyze and evaluate the level of students' ecological literacy, to exercise self-control and self-assessment), research (mastery of research methods) nature, the ability to conduct field research, use modern equipment for this purpose); special creative skills (design posters and wall newspapers, arrange exhibitions, sketch objects in nature, take photographs, make video); the ability to follow the rules of behavior in nature (Bilianska, 2017).

Measurement of the formation of value and procedural components of the students' ability to form schoolchildren's ecological literacy was carried out using a three-point scale $(0$, 1,2 points). The maximum possible amount of points scored was as follows: value component 14 points, procedural -18 points. The cognitive component was measured by the results of students' control work, which consisted of 40 tests, 10 short-answer tasks and was rated at 50 points maximum.

\section{Data Analysis}

During the analysis, the minimum $\left(C_{\text {min }}\right)$ and maximum $\left(C_{\text {max }}\right)$ coefficients of forming value, cognitive and procedural components of future Biology teachers' ability to foster students' ecological literacy were used. The calculations were carried out based on the research model by Prybora (2011). Based on the obtained results, the calculation of the limits of oscillations $\Delta \mathrm{C}$ for each component and the value $\Delta \mathrm{c}$, which changed the results of two measurements for each of the indicators. 
Mariia BILIANSKA, Olga YAROSHENKO. Ability to foster schoolchildren's ecological literacy as a result of prospective biology teachers' professional training

PROBLEMS

OF EDUCATION IN THE $21^{\text {st }}$ CENTURY Vol. 78, No. 6,2020

912
For the cognitive component, the average value of the coefficient of knowledge acquisition $C_{k \text { aver }}$ was calculated according to the formula adapted for research (Kyveryalg, 1980):

$$
C_{k \text { aver }}=\frac{\sum n_{k i}}{\sum N_{k}}
$$

where $\sum n_{k i}$ - the number of correct answers of all students,

$\sum N_{k}$ - the number of maximum possible correct answers.

The obtained results of pedagogical research were checked to the extent of their randomness by means of the criterion of homogeneity $\chi^{2}$.

In order to identify coincidences and differences for the experimental data, the two statistical hypotheses: zero and alternative were compared. According to the zero hypothesis, the obtained results do not contain differences; according to the alternative, the probability of error does not exceed 5\% (significance level .05). Hypotheses were tested for each component of the studied phenomenon by comparing the results of the ascertaining and formative (final section) stages of the pedagogical experiment.

\section{Research Results}

At the ascertaining stage of the pedagogical experiment, it was revealed that the cycle of elective disciplines is less involved in training future Biology teachers for increasing students' ecological literacy. It lacks disciplines, the tasks of which is to provide a purposeful influence on developing future Biology teachers' research ability. The predominance of the average level of prospective Biology teachers' ability to form students' ecological literacy in all components has also been revealed. Among the participants of the ascertaining stage of the pedagogical experiment, there was identified the least number of students with a high level of formation of each component as presented in Table 1 .

Table 1

The Results of the Ascertaining Stage of the Pedagogical Experiment

\section{Levels of formation}

\begin{tabular}{lllllll}
\cline { 2 - 7 } Components of ability & \multirow{2}{*}{ Low } & & Average & \multicolumn{3}{c}{ High } \\
\cline { 2 - 7 } & $\mathrm{N}$ & $\%$ & $N$ & $\%$ & $N$ & $\%$ \\
\hline Value & 47 & 37 & 68 & 53 & 13 & 10 \\
\hline Cognitive & 37 & 29 & 66 & 51 & 25 & 20 \\
\hline Procedural & 52 & 41 & 66 & 51 & 10 & 8 \\
\hline
\end{tabular}

The training of future biology teachers for increasing students' ecological literacy was carried out in the process of studying elective disciplines "Conducting Ecological Pedagogical Activities", "Technologies of Environmental Education and Upbringing", "Methods of Teaching Ecology". The duration of studying each discipline was 2 ECTS credits (Bilianska, 2016).

In accordance with the content of these disciplines, lectures and practical classes were aimed at developing pre-service teachers' ability to form students' environmental literacy. In practical classes, future biology teachers trained in conducting environmental games, environmental events, environmental parties, debates, exhibitions, poster competitions, and environmental tours. They learned how to organize students' research activities in the Small Academy of Sciences and do environmental projects. In the process, the interactive teaching methods were used. The students also analyzed the content and structure of current curricula in Biology and Ecology; determined what didactic opportunities for the formation of students' 
Mariia BILIANSKA, Olga YAROSHENKO. Ability to foster schoolchildren's ecological literacy as a result of prospective biology teachers' professional training

PROBLEMS

OF EDUCATION

IN THE $21^{\text {st }}$ CENTURY

Vol. 78 , No. 6, 2020

environmental literacy are endowed with specific topics; trained in planning lessons and extracurricular activities; learned to rationally combine methods and means of teaching, to model educational projects of ecological content. Experimental training also included the implementation of higher education students' tasks for the development of training sessions and educational activities on environmental issues.

In order to get prepared for the formation of students' environmental literacy, future teachers created concept maps for conducting environmental pedagogical activities with students of all age groups. Interactive learning was used during working process (Skyba, 2016a; 2016b). The designed programs of elective disciplines "Conducting Ecological Pedagogical Activities", "Technologies of Environmental Education and Upbringing", "Methods of Teaching Ecology" and appropriate teaching and methodological support for their studying modernized the training of pre-service Biology teachers for increasing students' ecological literacy.

The dynamics of developing future Biology teachers' ability to form students' ecological literacy during the formative stage of the pedagogical experiment can be traced according to Table 2, comparing the results of the initial $\left(\mathrm{F}_{1}\right)$ and final $\left(\mathrm{F}_{2}\right)$ sections.

\section{Table 2}

The Results of the Formative Stage of the Pedagogical Experiment (In \%)

\begin{tabular}{llllllllll}
\hline & \multicolumn{1}{c}{ Levels of formation } \\
\cline { 2 - 11 } $\begin{array}{l}\text { Components } \\
\text { of ability }\end{array}$ & Low & \multicolumn{9}{c}{ Average } \\
\cline { 2 - 11 } & $\mathrm{F}_{1}$ & $\mathrm{~F}_{2}$ & Increase & $\mathrm{F}_{1}$ & $\mathrm{~F}_{2}$ & Increase & $\mathrm{F}_{1}$ & $\mathrm{~F}_{2}$ & Increase \\
\hline Value & 38 & 28 & -10 & 41 & 48 & +7 & 21 & 24 & +3 \\
\hline Cognitive & 22 & 14 & -8 & 54 & 57 & +3 & 24 & 29 & +5 \\
\hline Procedural & 36 & 29 & -7 & 50 & 53 & +3 & 14 & 18 & +4 \\
\hline
\end{tabular}

The average value of the coefficient of knowledge acquisition $C_{k \text { aver }}$ at the ascertaining stage of the pedagogical experiment was .522, at the formative stage (initial section) - .641. Using the established in didactics approach to the assessment of learning outcomes as positive, if the coefficient of knowledge acquisition is .7 and higher (Bespalko, 1977), both results were concluded to correspond to a low level. At the same time, this indicator was equal to .720, according to the results of the final section, i.e., confirmed the effectiveness of the experimental method. Visually, the results of the pedagogical experiment are illustrated in Figure 1.

\section{Figure 1}

The Results of the Ascertaining (A) and Formative Stages (F1, F2) of the Pedagogical Experiment

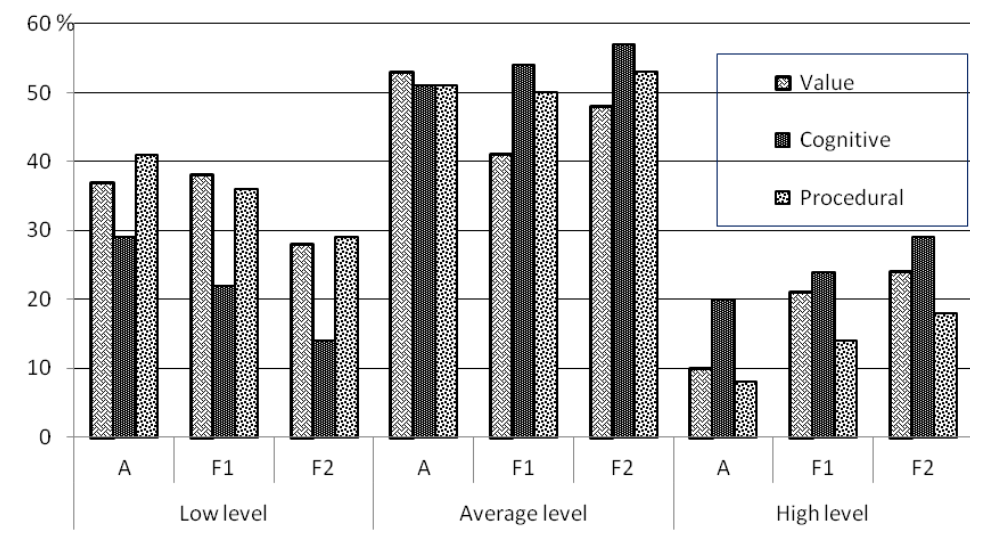


Mariia BILIANSKA, Olga YAROSHENKO. Ability to foster schoolchildren's ecological literacy as a result of prospective biology teachers' professional training

PROBLEMS

OF EDUCATION

IN THE $21^{\text {st }}$ CENTURY

Vol. 78, No. 6, 2020

914

Verification of the results of the pedagogical experiment concerning their randomness showed that the value of $\chi_{\text {emp }}^{2}$ for the value component is 8.76 , cognitive -8.18 , procedural 6.93, while the critical value of the homogeneity criterion $\chi^{2} .05$ is 5.99 (Novikov, 2004). Thus, the null hypothesis was not confirmed. Verification of statistical significance confirmed the reliability of the obtained results at the level of $95 \%$.

Based on a survey of teachers with teaching experience up to 5 years, it was found out that $13.2 \%$ consider themselves fully prepared for increasing students' ecological literacy, $21.9 \%$ - more prepared than unprepared, $62.8 \%$ - more unprepared, than prepared and only $2.1 \%$ - completely unprepared. Regarding the desire to develop their ability to form students' ecological literacy, the answers of the respondents were as follows: $68.3 \%$ had a stable desire, $28.8 \%$ - more unstable than stable, $1.8 \%$ - unstable, $1.1 \%$ - lack of desire. The teachers have proved to be aware of the importance and necessity of developing students' ecological literacy. At the same time, most of them consider themselves insufficiently prepared for this type of activity and in individual interviews noted that preparation for this type of professional activity at university is carried out sporadically.

\section{Discussion}

The diagnosis of prospective Biology teachers' readiness for increasing students' environmental literacy was carried out by value, cognitive and procedural components and at three levels, which generally coincides with the position of Kornilova (2020). However, the researcher prefers the concept "motivation to work" instead of "values". Shapran (2012) paid attention to the aesthetic perception of nature, which can be attributed to the value component.

For each component of the phenomenon under analysis, the results obtained in the research are characterized by a negative increase in the number of students with a low level of ability to form ecological literacy and a positive increase with average and high levels. The largest negative increase in the number of students with a low level of ability to develop schoolchildren's environmental literacy is observed for the value component $(-10 \%)$. At the same time, at the average level there is the largest positive increase in the formation of this component. This suggests a change in future Biology teachers' beliefs concerning the awareness of their personal involvement and responsibility for the conservation of natural resources; caring for the living beings and conducting environmental activities have become a priority for them. According to the observations of the teachers taking part in the experiment, future Biology teachers began to become more involved in environmental activities and they tried to conduct them with students during teaching practice at school.

This conclusion correlates with the results of the research by Avdyeyeva (2003), which showed the fact that students care about environmental issues, are aware of the need to preserve it, but do not realize the need to solve problems comprehensively.

It is explained by the fact that according to the experimental method, the students took an active part in environmental activities, and organized them during their pedagogical practice at school. The use of project activities, creative (exhibitions, poster competitions, etc.) and situational tasks in the process of studying the developed elective disciplines proved favorable. These results coincide with the conclusions about the positive impact of interactive methods on the formation of future teachers' environmental competence (Koldomasova, 2005; Shapran, 2012; Wanchana et al., 2019).

It is assumed that the decrease in the number of respondents with the low level of the cognitive component is due to increasing information by introducing elective disciplines "Conducting Ecological Pedagogical Activities", "Technologies of Environmental and Upbringing", "Methods of Teaching Ecology" and the use of interactive teaching methods. The study of these disciplines proved helpful and gave future Biology teachers the opportunity to 
learn about the forms, methods and means of developing ecological literacy, to get acquainted with advanced pedagogical experience, modern achievements of domestic and foreign teachers in ecological education and upbringing, with interactive technologies for increasing ecological literacy. The positive increase in the formation of this component was the largest at a high level. This is correlated with the growth of the value of the coefficient of knowledge acquisition during the pedagogical experiment.

There are also other, alternative ways of developing ecological awareness (cognitive component) - in the process of studying only obligatory disciplines of biological and ecological slant (Koldomasova, 2005; Kornilova, 2020). One of the pedagogical conditions for the formation of ecological culture of pre-service teachers of natural sciences is the greening of the content of education on the basis of interdisciplinary integration (Honcharuk, 2019).

The test results were unexpected. The students gave the most incorrect answers to a block of questions concerning theoretical questions of General Ecology - the doctrine of population, the relationship of living organisms with the environment, and global environmental problems. This suggests the need to pay more attention to the study of the discipline "General Ecology", as this knowledge is the basis for teaching the topics "Ecology" and "Sustainable Development and Environmental Management" in the course "Biology" in high school (11th grade) (Navchal'ni prohramy 10-11 klasiv, 2018a, 2018b). In addition, the analysis of the students' responses showed that more attention should be paid to educational material related to methods of forming students' ecological literacy, as $31 \%$ of students did not cope with these tasks at the initial testing of the formative stage.

Such research results in this aspect coincide with the conclusions of Roczen et al. (2013) on the low level of students' mastery of theoretical knowledge, in particular about the ecosystem. However, a careful attitude to nature encourages people to expand and deepen their knowledge (Esa, (2010).

It should be mentioned that the increase in the high level of formation of the future Biology teachers' ability to develop students' ecological literacy for the value and procedural components was also positive, although somewhat smaller. Regarding the formation of students skills in fostering schoolchildren's ecological literacy, according to the observations of experimental teachers, there were no problems with the formation of organizational, and research skills', as well as the ability to follow the rules of behavior in nature. The formation of cognitive (the ability to apply the educational potential of the school subject of Biology for increasing students' ecological literacy); projective (ability to plan activities for the formation of students' ecological literacy); constructive (ability to use tools, teaching methods to achieve goals and objectives) skills needs special attention. For their formation, practical classes in the introduced elective disciplines prove promising. However, Kornilova (2020) has singled out a much narrower range of skills - the ability to formulate a problem question, the ability to determine the purpose of the conversation, the ability to select the content of material, the ability to stimulate student activity, the ability to analyze the conversation and achieve results. Experimental teachers showed a somewhat slow formation of students' ability to use the educational potential of the school subject of Biology for increasing students' ecological literacy. Based on this, the use of interactive methods for educational purposes seems promising in the future.

Thus, the dynamics of development of prospective Biology teachers' ability to form students' ecological literacy by using the experimental technology of student training is positive. This indicates that introducing the elective disciplines "Conducting Ecological Pedagogical Activities", "Technologies of Environmental Education and Upbringing", "Methods of Teaching Ecology" and the developed for their study educational and methodological support was appropriate. 
Mariia BILIANSKA, Olga YAROSHENKO. Ability to foster schoolchildren's ecological literacy as a result of prospective biology teachers' professional training

PROBLEMS

OF EDUCATION

IN THE $21^{\text {st }}$ CENTURY

Vol. 78, No. 6, 2020

916

\section{Conclusions and Implications}

The practice-oriented nature of the experimental technology of training pre-service teachers to form students' ecological literacy, its implementation in the educational process in the classroom, in independent work, practical training, control activities, and extensive use of interactive teaching methods optimized the educational process and provided successful training for pre-service teachers for increasing schoolchildren's ecological literacy. The results of the pedagogical experiment give evidence to it. Within statistically significant limits, there have been positive changes in the levels of formation of all components of pre-service Biology teachers' ability to foster students' ecological literacy. The average level of formation of all the components prevails.

This confirms the expediency of widespread introduction of the developed technology of training future biology teachers for the formation of students' ecological literacy in order to improve the quality of professional training of students of higher pedagogical education. As a result, schools will be provided with teachers who, in the process of studying Biology, will form ecological literacy of conscious students who are responsible for preservation of the environment.

The research was conducted during a real educational process. However, with the introduction of quarantine restrictions due to the Covid-19 pandemic, the share of online classes has increased. Additional research is required on the impact of distance learning on the results of training pre-service Biology teachers to form students' ecological literacy. In the future, research on the use of information technology, as well as preparing university students for the implementation of scientific environmentally oriented education of schoolchildren is relevant.

\section{References}

Adawiah, R., \& Esa, N. (2013). Ecological literacy among secondary school students. In CoSMEd 2013 5th International Conference on Science and Mathematics Education (11-14 November, Penang, Malaysia). https://www.researchgate.net/publication/263011210_Ecological_Literacy_among_Secondary_ School_Students

Aksan, Z., \& Çelikler, D. (2020). Creating awareness of pre-service science teachers for sustainable development about waste recycling. International Electronic Journal of Environmental Education, 10(2), 147-166. https://files.eric.ed.gov/fulltext/EJ1256288.pdf

Avaroğulları, M., \& Ayılmazdır, H. (2019). Teacher candidates' behaviors towards environment and some factors affecting them. International Journal of Environmental \& Science Education, 14(4), 127138. http://www.ijese.net/makale_indir/IJESE_2109_article_5ce3cae248105.pdf

Avdyeyeva, V. V. (2008). Pidhotovka maybutnikh uchyteliv biolohiyi do ekolohichnoyi osvity starshoklasnykiv [Training of future biology teachers for ecological education at high school]. Visnyk Zhytomyrs'koho derzhavnoho universytetu imeni Ivana Franka, 12, 141-143. http://eprints. zu.edu.ua/789/1/35.pdf

Berkowitz, A. R., Ford, M. E., \& Brewer, C. A. (2005). A framework for integrating ecological literacy, civics literacy, and environmental citizenship in environmental education. In E. A. Johnson, \& M. J. Mappin (Eds.), Environmental education or advocacy: Perspectives of ecology and education in environmental education (pp. 227-265). Cambridge University Press.

Bespalko, V. P. (1977). Osnovy teorii pedagogicheskih sistem: Problemy $i$ metody psihologopedagogicheskogo obespecheniya tehnicheskih obuchayushih sistem [Fundamentals of the theory of pedagogical systems: Problems and methods of psychological and pedagogical support of technical training systems]. Izd-vo Voronezhskogo universiteta.

Bilianska, M. M. (2016). Praktyko-oriyentovani navchal'ni prohramy pidhotovky studentiv spetsial'nosti 014 "Serednya osvita (biolohiya)". [Practice-oriented curricula for students majoring in 014 "Secondary Education (Biology)"]. Bahira. 
Mariia BILIANSKA, Olga YAROSHENKO. Ability to foster schoolchildren's ecological literacy as a result of prospective biology teachers' professional training

$\mid \begin{aligned} & \text { PROBLEMS } \\ & \text { OF EDUCATION } \\ & \text { IN THE } 21^{\text {st }} \text { CENTURY } \\ & \text { Vol. 78, No. 6, } 2020\end{aligned}$

Bilianska, M. M. (2017). Pidhotovka maybutnikh uchyteliv biolohiyi do ekoloho-pedahohichnoyi diyal'nosti v zahal'noosvitnikh navchal'nykh zakladakh /Monohrafiya/ [Preparation of future biology teachers for ecological pedagogical activities in secondary schools]. NPU imeni M. P. Dragomanova.

Boychenko, S. V., \& Sayenko, T. V. (2013). Ekolohichna osvita - osnova staloho rozvytku suspil'stva. Problemy $i$ perspektyvy vyshchoyi shkoly /Monohrafiya/ [Ecological education is the basis of sustainable development of society. Problems and prospects of high school]. Universytet "Ukrayina".

Esa, N. (2010). Environmental knowledge, attitude and practices of student teachers. International Research in Geographical and Environmental Education, 19(1), 39-50. https://doi.org/10.1080/10382040903545534

Hay, D., Kinchin, I., \& Lygo-Baker, S. (2008). Making learning visible: The role of concept mapping in higher education. Studies in Higher Education, 33(3), 295-311. https:/edisciplinas.usp.br/ pluginfile.php/2745278/mod resource/content/4/EDM-5103-4-A8.pdf

Hlobal'ni tsili staloho rozvytku 2015-2030. (2015). [Global Sustainable Development Goals 2015-2030]. https://www.ua.undp.org/content/ukraine/uk/home/sustainable-development-goals.html

Honcharuk, V. V. (2019). Formuvannya ekolohichnoyi kul'tury maybutnikh uchyteliv pryrodnychykh spetsial'nostey u protsesi profesiynoyi pidhotovky [Development of ecological culture among future environmental teachers during professional training]. Khmel'nyts'kyy. http://elar.khnu.km.ua/ jspui/bitstream/123456789/8824/1/Гончарук.pdf

Jordan, R., Singer, F., Vaughan, J., \& Berkowitz, A. (2009). What should every citizen know about ecology? Frontiers in Ecology and the Environment, 7(9), 495-500. https://doi.org/10.1890/070113

Kaiser, F. G., \& Fuhrer, U. (2003). Ecological behavior's dependency on different forms of knowledge. Applied Psychology, 52(4), 598-613. https://doi.org/10.1111/1464-0597.00153

Kapskaya, A. I. (1989). Formirovanie gotovnosti studentov pedvuza k ispolnitelsko-rechevoj deyatelnosti $v$ sisteme professionalnoj podgotovki /Avtoref. diss. ... d-ra ped. nauk/ [Formation of readiness of pedagogical university students for executive speech activity in the system of professional training]. KGPI imeni A. M. Gorkogo.

Koldomasova, L. S. (2005). Formirovanie ekologicheskoj obrazovannosti studentov v processe professionalnoj podgotovki [Development of students' ecological education during professional training] / Avtoreferat diss.... kand. ped. nauk / Magnitogorsk. http://nauka-pedagogika.com/ pedagogika-13-00-08/dissertaciya-formirovanie-ekologicheskoy-obrazovannosti-studentov-vprotsesse-professionalnoy-podgotovki

Kornilova, L. A. (2020). Podgotovka budushih pedagogov $k$ formirovaniyu ekologicheskogo mirovozzreniya u starsheklassnikov [Training of future teachers for development of ecological outlook among high school students] / Diss.... kand. ped. nauk/. Volgograd. https://www.sgu.ru/ sites/default/files/dissertation/2020/02/03/dissertaciya.pdf

Kuzmina, N. V. (1990). Professionalizm lichnosti prepodavatelya i mastera proizvodstvennogo obucheniya [Professionalism of the personality of the teacher and the master of industrial training]. Vysshaya shkola.

Kyveryalg, A. A. (1980). Metody issledovaniya v professionalnoj pedagogike [Research methods in professional pedagogy]. Valgus.

McBeth, B., Hungerford, H., Marcinkowski, T., Volk, T., \& Meyers, R. (2008). National Environmental Literacy Assessment Project: Year 1, National Baseline Study of Middle Grades Students Final Research Report. Environmental Protection Agency. https://www.noaa.gov/sites/default/files/ atoms/files/Final_NELA_minus_MSELS_8-12-08_0.pdf

McBride, B. B., Brewer, C. A., Berkowitz, A. R., \& Borrie, W. T. (2013). Environmental literacy, ecological literacy, ecoliteracy: What do we mean and how did we get here? Ecosphere, 4(5), 1-20. http://dx.doi.org/10.1890/ES13-00075.1

Molyako, V. O. (1989). Psykholohichna hotovnist' do tvorchoyi pratsi [Psychological readiness for creative work]. Znannya.

Navchal'ni prohramy 10-11 klasiv. (2018a). Biolohiya i ekolohiya 10-11 kl. Riven' standartu [Curricula for grades 10-11. Biology and Ecology 10-11 forms. Standard level]. https://mon.gov.ua/ua/ osvita/zagalna-serednya-osvita/navchalni-programi/navchalni-programi-dlya-10-11-klasiv 
Mariia BILIANSKA, Olga YAROSHENKO. Ability to foster schoolchildren's ecological literacy as a result of prospective biology teachers' professional training

PROBLEMS

OF EDUCATION IN THE $21^{\text {st }}$ CENTURY Vol. 78, No. 6, 2020

918

Navchal'ni prohramy 10-11 klasiv. (2018b). Biolohiya i ekolohiya 10-11 kl. Profil'nyy riven' [Curricula for grades 10-11. Biology and Ecology 10-11 forms. Profile level]. https://mon.gov.ua/ua/osvita/ zagalna-serednya-osvita/navchalni-programi/navchalni-programi-dlya-10-11-klasiv

North American Association for Environmental Education (NAAEE). (2000). Excellence in environmental education: guidelines for learning (K-12). NAAEE. https://cdn.naaee.org/sites/default/files/ learnerguidelines_new.pdf

North American Association for Environmental Education (NAAEE). (2011). Developing a framework for assessing environmental literacy. NAAEE. https://cdn.naaee.org/sites/default/files/ devframewkassessenvlitonlineed.pdf

Nova ukrayins'ka shkola. (2016). Kontseptual'ni zasady reformuvannya seredn'oyi shkoly [The new Ukrainian School. Conceptual principles of secondary school reform]. https://mon.gov.ua/storage/ app/media/zagalna\%20serednya/nova-ukrainska-shkola-compressed.pdf

Novikov, D. A. (2004). Statisticheskie metody v pedagogicheskih issledovaniyah (tipovye sluchai) [Statistical methods in pedagogical research (typical cases)]. MZ-Press.

Orr, D. W. (1992). Ecological Literacy: Education and the transition to a postmodern world. State University of New York Press.

Panfilova, L. V. (2002). Formirovanie ekologicheskoj kompetentnosti v processe professionalnoj podgotovki uchitelya himii /Diss. ... d-ra ped. nauk/ [Formation of ecological competence in the process of professional training of a chemistry teacher]. Tolyatinskij gos. un-t.

Powers, J. (2010). Building a Lasting Foundation in Ecological Literacy in Undergraduate, Non-majors Courses. Nature Education Knowledge, 3(10), 53. https:/www.nature.com/scitable/knowledge/ library/building-a-lasting-foundation-in-ecological-literacy-13239771/

Prybora, N. A. (2011). Pidhotovka maybutn'oho vchytelya do vykorystannya khimichnoho eksperymentu $v$ zahal'noosvitnikh navchal'nykh zakladakh /Dyss. ... kand. ped. nauk/ [Training future teachers for use of chemical experiment in general educational institutions]. NPU imeni M. P. Dragomanova.

Roczen, N., Kaiser, F. G., Bogner, F. X., \& Wilson, M. (2013). A competence model for environmental education. Environment and Behavior, 46(8), 972-999. https://doi.org/10.1177\%2F0013916513492416

Shapran, Yu. P. (2012). Ekolohichna kompetentnist' maybutnikh uchyteliv biolohiyi: yiyi sutnist' ta diahnostyka [Ecological competence of future biology teachers: It's essence and diagnostics]. Dostizheniya nauki za poslednie gody. Novye narabotki, 29-36. http://конференция.com.ua/files/ image/konf\%2012/doklad_12_3-2_06.pdf

Shtul'man, E. A. (1988). Specifika metodicheskogo eksperimenta [Particular characteristics of the methodical experiment]. Sovetskaya pedagogika [Soviet pedagogy], 3, 61-65.

Skyba, M. (2016a). Zastosuvannya keys-metodu dlya formuvannya konstruktyvnykh i proektyvnykh umin' ekoloho-pedahohichnoyi diyal'nosti [The appliance of case method to produce constructive and projective competences of ecologo-pedagogical activity] Pedahohichni nauky: teoriya, istoriya, innovatsiyni tekhnolohiyi [Pedagogical sciences: theory, history, innovative technologies], 4(58), 354-362. SumDPU imeni A. S. Makarenka. http://enpuir.npu.edu.ua/handle/123456789/26710

Skyba, M. M. (2016b). Interaktyvni metody navchannya dystsyplin ekoloho-pedahohichnoho spryamuvannya u vyshchomu navchal'nomu zakladi. [Interactive training methods of teaching ecologo-pedagogical disciplines at higher education institution] Naukovi zapysky Ternopil's 'koho natsional'noho pedahohichnoho universytetu imeni Volodymyra Hnatyuka. Seriya: pedahohika [The Scientific Issues of Ternopil Volodymyr Hnatiuk National Pedagogical University. Section: pedagogy], 1, 51-56.

Traulko, E. V. (2004). Proektirovanie lichnostno orientirovannoj ekologicheskoj podgotovki studentov nebiologicheskih specialnostej /Avtoref. diss. ... kand. ped. nauk/ [Design of personality-oriented ecological training of students of non-biological specialties]. Novosibirskij gos. tehn. un-t.

Tuncer, G., Tekkaya, C., Sungur, S., Cakiroglu, J., Ertepinar, H., \& Kaplowitz, M. (2009). Assessing pre-service teachers' environmental literacy in Turkey as a mean to develop teacher education programs. International Journal of Educational Development, 29(4), 426-436. https://doi.org/10.1016/j.ijedudev.2008.10.003

Urus'kyy, V. I. (2005). Formuvannya hotovnosti vchyteliv do innovatsiynoyi diya'nosti /Metodychnyy posibnyk/ [Formation of teachers' readiness for innovative activity]. TOKIPPO. 
Mariia BILIANSKA, Olga YAROSHENKO. Ability to foster schoolchildren's ecological literacy as a result of prospective biology teachers' professional training

PROBLEMS

OF EDUCATION

IN THE $21^{\text {st }}$ CENTURY

Vol. 78 , No. 6, 2020

Wanchana, Y., Inprom, P., Rawang, W., \& Ayudhya Art-ong Jumsai Na. (2019). A model of environmental education competency development for teachers in secondary schools. International Journal of Environmental \& Science Education, 14(9), 511-520. http://www.ijese.net/makale/2141.html

Received: July 30, 2020

Accepted: November 18, 2020

Cite as: Bilianska, M., \& Yaroshenko, O. (2020). Ability to foster schoolchildren's ecological literacy as a result of prospective biology teachers' professional training. Problems of Education in the $21^{\text {st }}$ Century, 78(6), 907-919. https://doi.org/10.33225/pec/20.78.907

\section{Mariia Bilianska}

(Corresponding author)
Doctor, Associate Professor at National Pedagogical Dragomanov University, Pyrohova str., 9 Kyiv 01601, Ukraine.

E-mail: mmbilianska@gmail.com, mbilianska@ukr.net

Website: https://scholar.google.com/citations?view_op=list_ works\&hl=ru\&user=KXqnrn8AAAAJ

ORCID: https://orcid.org/0000-0001-6916-8993

Olga Yaroshenko
Doctor of Pedagogical Sciences, Professor, Full Member (academician) of the National Academy of Pedagogical Sciences of Ukraine, Leading Scientific Researcher of the Department of integration of higher education and science, Institute of Higher Education of the National Academy of Educational Sciences of Ukraine, Bastionna str., 9 Kyiv 01014, Ukraine.

E-mail: o.yaroshenko@ihed.org.ua, yaroshenko_o@ukr.net

Website: https://scholar.google.com.ua/citations?user=_Y1NQ3QAAAAJ\&hl=ru ORCID: https://orcid.org/0000-0003-1555-0526 